\title{
PENINGKATAN AKTIVITAS DAN HASIL BELAJAR AKUNTANSI MELALUI IMPLEMENTASI MODEL PEMBELAJARAN KOOPERATIF TEAMS GAMES TOURNAMENT
}

\section{IMPROVING ACCOUNTING ACTIVITIES AND LEARNING OUTCOMES BY IMPLEMENTING COOPERATIVE LEARNING MODEL TEAMS GAMES TOURNAMENT}

\author{
Oleh: \\ Marfuatun Nashiroh
}

Prodi Pendidikan Akuntansi, Universitas Negeri Yogyakarta marfuatun.nashiroh2016@student.uny.ac.id

Prof. Sukirno, M.Si., Ph. D.

Staff Pengajar Jurusan P. Akuntansi, Universitas Negeri Yogyakarta sukirno@uny.ac.id

\begin{abstract}
Abstrak
Penelitian ini bertujuan untuk meningkatkan Aktivitas dan Hasil Belajar Akuntansi Siswa Kelas X AKL 2 SMK Negeri 1 Pengasih Tahun Ajaran 2019/2020 melalui implementasi Model Pembelajaran Kooperatif Tipe Teams Games Tournament (TGT). Penelitian ini merupakan Penelitian Tindakan Kelas yang dilaksanakan dalam dua siklus. Teknik pengumpulan data yang digunakan adalah observasi partisipatif, tes, dokumentasi, dan catatan lapangan. Teknik analisis data dalam penelitian ini yaitu analisis data deskriptif kuantitatif. Hasil penelitian dapat disimpulkan bahwa implementasi Model Pembelajaran Kooperatif Tipe Teams Games Tournament (TGT) dapat meningkatkan Aktivitas dan Hasil Belajar Akuntansi Siswa. Skor rata-rata Aktivitas Belajar Akuntansi meningkat dari siklus I sebesar 73,44\% menjadi 88,47\% pada siklus II. Rata-rata Hasil Belajar Akuntansi pada pre test siklus I sebesar 32,27 meningkat menjadi 76,63 pada post test. Pada siklus II, rata-rata Hasil Belajar Akuntansi pre test sebesar 30,81 meningkat menjadi 88,80 pada post test. Ketuntasan Hasil Belajar Akuntansi pada I sebesar 65,71\%. Pada siklus II, Ketuntasan Hasil Belajar Akuntansi sebesar 88,57\%.
\end{abstract}

Kata kunci: Aktivitas Belajar Akuntansi, Hasil Belajar Akuntansi, TGT.

\section{Abstract}

This study aims to improve the Students' Accounting Activities and Learning Outcomes of class X AKL 2 SMK Negeri 1 Pengasih in the academic year of 2019/2020 by implementing Cooperative Learning Model Type of Teams Games Tournament (TGT). This study is classified as a Classroom Action Research (CAR) implemented in two cycles. The data collection techniques used an observation, a test, and field notes. The data were analyzed by a quantitative descriptive data analysis. The result it can be concluded that the implementation of Cooperative Learning Model Type of Teams Games Tournament (TGT) can improve the Students' Accounting Activities and Learning Outcomes. The average score of Accounting Learning Activities increased $73.44 \%$ on the cycle I to $88.47 \%$ on the cycle II. The Average Accounting Learning Outcomes from the cycle I in the pre test was 32.27 increased to 76.63 in the post test. On the cycle II, The Average Accounting Learning 
Outcomes in the pre test was 30.81 increased to 88.80 in the post test. On the cycle I, The Accounting Learning Outcomes Completeness was 65.71\%. On the cycle II, The Accounting Learning Outcomes Completeness was $88.57 \%$.

Keywords: Accounting Learning Activities, Accounting Learning Outcomes, TGT.

\section{PENDAHULUAN}

Pendidikan merupakan proses pengubahan sikap dan perilaku seseorang atau kelompok orang dalam usaha mendewasakan manusia melalui upaya pengajaran dan pelatihan, proses, perbuatan, dan cara mendidik. Pembelajaran merupakan proses kegiatan belajar mengajar yang juga berperan dalam menentukan keberhasilan belajar siswa. Pembelajaran adalah proses yang di dalamnya terdapat kegiatan interaksi antara guru dengan siswa, baik interaksi secara langsung seperti kegiatan tatap muka maupun secara tidak langsung yaitu dengan menggunakan berbagai media pembelajaran (Rusman, 2016 : 134).

Salah satu masalah yang masih sering dihadapi dunia pendidikan di Indonesia adalah lemahnya pembelajaran yang dikembangkan oleh guru. Hal tersebut sejalan dengan yang dikemukakan oleh Menteri Pendidikan dan Kebudayaan Republik Indonesia, Bapak Nadiem Makarim bahwa dasar permasalahan pendidikan adalah ada di dalam kelas, yaitu apa yang terjadi antara siswa dengan guru. Siswa kurang didorong untuk aktif dalam pembelajaran, sehingga pembelajaran di dalam kelas hanya diarahkan kepada kemampuan siswa untuk menghafal pelajaran. Pada umumnya, guru hanya mengajar dengan model ceramah dan latihan saja. Selain itu, guru hanya menggunakan komunikasi satu arah atau tidak berusaha mengajak siswa untuk berpikir dan tidak meminta feedback dari siswa. Menurut Rina (2016: 2) apabila pembelajaran terus dilaksanakan dalam kondisi komunikasi satu arah maka dikhawatirkan akan semakin menurunkan keberhasilan proses pembelajaran.

Pendidikan tidak hanya ditujukan untuk mencapai hasil belajar, tetapi juga melibatkan proses belajar yang terjadi dalam diri anak. Proses dan hasil belajar merupakan dua hal yang saling berkaitan, di mana hasil merupakan akibat dari proses (Sudjana, 2014: 3). Baik proses maupun hasil belajar, keduanya harus berjalan seimbang.

Permasalahan dalam penelitian ini adalah masih rendahnya Aktivitas dan Hasil belajar Akuntansi Siswa di SMK Negeri 1 Pengasih. Hal tersebut terjadi karena selama ini guru hanya menggunakan metode ceramah, media power point, buku paket, dan soal latihan. Berdasarkan hasil observasi diperoleh data sebagai berikut.

\begin{aligned} & Tabel \multicolumn{3}{l}{ Hasil Observasi Kegiatan Pembelajaran di Kelas } \\ & \cline { 2 - 2 } Terlihat mengantuk $17 \% \\ &$\hline Kurang berkonsentrasi $33 \% \\ &$\hline $\begin{array}{l}\text { Mengobrol dan bercanda } \\ \text { dengan teman }\end{array} 17 \% \\ &$\hline $\begin{array}{l}\text { Memperhatikan tetapi tidak } \\ \text { mencatat }\end{array} 33 \% \\ &$\hline\end{aligned}

Sumber: Data Primer yang Diolah

Nilai Siswa pada Penilaian Tengah Semester (PTS) dan Penilaian Akhir Semester (PAS) Gasal mata pelajaran Akuntansi Dasar menunjukkan bahwa Hasil Belajar Akuntansi Siswa Kelas X AKL 2 SMK Negeri 1 Pengasih tahun ajaran 2019/2020 masih tergolong rendah. Hal tersebut ditunjukkan pada nilai siswa yang mencapai Ketuntasan Kriteria 
Minimal (KKM) masih di bawah 75\%. KKM mata pelajaran Akuntansi Dasar adalah 75. Berdasarkan nilai PTS dan PAS yang ada, maka diperoleh data sebagai berikut.

\begin{tabular}{ccc} 
Tabel 2 Hasil Belajar Akuntansi Dasar Siswa Kelas X AKL 2 \\
\cline { 2 - 3 } & Lulus KKM & $\begin{array}{c}\text { Belum Lulus } \\
\text { KKM }\end{array}$ \\
\hline \multirow{2}{*}{ PTS } & 9 siswa & 27 siswa \\
& $(25 \%)$ & $(75 \%)$ \\
\hline \multirow{2}{*}{ PAS } & 10 siswa & 26 siswa \\
& $(27,78 \%)$ & $(72,22 \%)$ \\
\hline
\end{tabular}

Sumber: Data Primer yang Diolah

Menurut Sudjana (2014: 3), hasil belajar pada hakikatnya adalah perubahan tingkah laku yang dalam pengertian luas mencakup bidang kognitif, afektif, dan psikomotorik. Hasil belajar menjadi akibat dari proses belajar. Model pembelajaran juga menjadi salah satu faktor yang mempengaruhi hasil belajar siswa seperti yang telah disebutkan sebelumnya. Meskipun terdapat faktor eksternal lain yang berpengaruh seperti lingkungan teman sebaya, suasana, dan prasarana belajar serta faktor internal seperti motivasi, keadaan jasmani, dan psikis siswa.

Amin, dkk (2018) menyimpulkan bahwa penggunaan model pembelajaran yang diterapkan oleh seorang guru merupakan salah satu faktor yang menentukan ketercapaian hasil belajar siswa, karena penggunaan model pembelajaran yang sesuai dengan materi yang disajikan mempengaruhi minat dan aktivitas siswa dalam mengikuti pelajaran yang pada akhirnya berpengaruh terhadap hasil belajar. Terdapat beberapa faktor yang harus dipertimbangkan dalam pemilihan metode mengajar, yaitu: kesesuaian dengan tujuan pembelajaran, perbedaan individu peserta didik, kemampuan guru, sifat bahan pelajaran, situasi kelas, fasilitas yang tersedia, serta kelebihan dan kelemahan dari metode pembelajaran. Menurut Sanjaya (2016: 249-250), model pembelajaran kooperatif dapat diterapkan untuk mengurangi ketergantungan siswa terhadap guru, memberdayakan siswa, meningkatakan prestasi, dan meningkatkan aktivitas belajar siswa.

Teams Games Tournament (TGT) merupakan salah satu jenis model pembelajaran kooperatif yang menggunakan turnamen akademik, dengan menggunakan kuis-kuis dan sistem skor kemajuan individu, di mana para siswa berlomba sebagai wakil tim mereka dengan anggota tim lain yang kinerja akademik sebelumnya setara seperti mereka (Slavin, 2016: 163-165). Ertikanto (2016:106) menyebutkan bahwa salah satu kelebihan Model Pembelajaran Kooperatif Tipe Teams Games Tournament adalah memperoleh hasil belajar yang lebih baik. Model pembelajaran Teams Games Tournament ini menawarkan suasana pembelajaran yang menyenangkan dan dikemas dalam bentuk turnamen atau kompetisi sehingga pada akhirnya diharapkan aktivitas dan hasil belajar siswa dapat mengalami peningkatan.

Berdasarkan latar belakang masalah yang telah diuraikan, tujuan penelitian ini adalah untuk Meningkatkan Aktivitas dan Hasil Belajar Akuntansi Siswa Kelas X AKL 2 SMK Negeri 1 Pengasih Tahun Ajaran 2019/2020 melalui Implementasi Model Pembelajaran Teams Games Tournament.

Aktivitas belajar merupakan kegiatan yang bersifat fisik maupun mental yaitu berbuat dan berpikir sebagai suatu rangkaian yang tidak dapat dipisahkan. Kedua aktivitas tersebut harus selalu berkait. Aktivitas siswa bukan hanya secara individual, tetapi juga dalam kelompok sosial. Aktivitas siswa dalam kelompok sosial akan menimbulkan adanya interaksi dalam kelompok Sardiman (2016: 100). Sanjaya (2016: 132) juga mengemukakan bahwa aktivitas tidak hanya terbatas pada aktivitas fisik, melainkan juga aktivitas psikis seperti 
aktivitas mental. Guru sering terkecoh dengan siswa yang pura-pura aktif, tetapi sebenarnya tidak. Berdasarkan definisi yang telah dikemukakan, dapat disimpulkan bahwa aktivitas belajar merupakan kegiatan atau proses yang dilakukan peserta didik baik secara fisik maupun nonfisik untuk memperoleh pengetahuan dan sebagai kemampuan bereaksi yang relatif tetap sebagai hasil latihan yang terus menerus dalam pembelajaran.

Jenis-jenis aktivitas belajar dibagi menjadi delapan menurut Dierech dalam Sardiman (2016: 101), yaitu: 1) visual activities; 2) oral activities; 3) listening activities; 4) writing activities; 5) drawing activities; 6) motor activities; 7) mental activities; dan 8) emotional activities.

Aktivitas dapat dikategorikan menjadi dua bentuk, yaitu aktivitas yang dapat diamati (konkret) dan aktivitas yang sulit diamati (abstrak). Aktivitas yang dapat diamati biasanya berhubungan dengan kerja otot (psikomotorik) berupa mendengar, menulis, membaca, menyanyi, menggambar, dan berlatih. Sedangkan aktivitas yang sulit diamati berupa kegiatan psikis (Suprihatiningrum, 2013:100).

Suprijono (2016: 5) mengemukakan bahwa hasil belajar merupakan pola-pola perbuatan, nilai-nilai, pengertian-pengertian, sikap-sikap, apresisasi, dan keterampilan. Menurut Sudjana (2016: 3), hasil belajar pada hakikatnya adalah perubahan tingkah laku yang dalam pengertian luas mencakup bidang kognitif, afektif, dan psikomotorik. Hasil belajar merupakan kemampuan-kemampuan yang dimiliki siswa setelah ia menerima pengalaman belajarnya.

Menurut Arifin (2016, 299-300) mengungkapkan bahwa guru harus memahami beberapa faktor yang dapat mempengaruhi hasil belajar, yaitu: 1) faktor peserta didik; 2) faktor sarana dan prasarana; 3) faktor lingkungan; 4) faktor hasil belajar.

Teams Games Tournament merupakan salah satu teknik yang digunakan dalam pembelajaran kooperatif. Pada model ini menggunakan turnamen akademik, menggunakan kuis-kuis dan sistem skor kemajuan individu, di mana para siswa berlomba sebagai wakil tim mereka dengan anggota tim lain yang kinerja akademiknya setara (Slavin, 2016: 163). Teams Games Tournament menempatkan siswa dalam kelompok-kelompok belajar yang beranggotakan 4-5 orang siswa yang memiliki kemampuan, jenis kelamin, dan suku atau ras yang berbeda.

Kegiatan belajar yang cenderung monoton dan satu arah akan mengakibatkan siswa mudah bosan dan sulit memahami materi yang belum pernah didapatkan sebelumnya. Aktivitas belajar merupakan salah satu prinsip yang penting dalam pembelajaran. Aktivitas dalam pembelajaran tidak hanya aktivitas guru dalam menyampaikan pelajaran namun juga aktivitas siswa sebagai subjek belajar. Aktivitas dan Hasil Belajar Akuntansi Siswa Kelas X AKL 2 tergolong masih rendah. Hal tersebut dibuktikan dengan sedikitnya siswa yang bertanya serta ketuntasan nilai PTS dan PAS yang masih rendah.

Proses dan hasil belajar merupakan dua hal yang saling berkaitan, di mana hasil merupakan akibat dari proses. Baik proses maupun hasil belajar, keduanya harus berjalan seimbang. Rendahnya aktivitas belajar secara tidak langsung turut berpengaruh terhadap hasil belajar siswa. Oleh sebab itu, diperlukan suatu model pembelajaran yang berpusat pada siswa sehingga mampu merangsang Aktivitas Belajar Akuntansi dan pada akhirnya meningkatkan Hasil Belajar Akuntansi.

Model pembelajaran menjadi salah satu faktor yang mempengaruhi aktivitas dan hasil belajar siswa. Terdapat banyak tipe model pembelajaran kooperatif yang dapat dipilih di antaranya adalah Tipe Teams Games Tournament (TGT). Tipe ini mampu memberikan suasana belajar yang menyenangkan dengan game atau permainan. Siswa dapat belajar bersama dengan teman sebaya sehingga diharapkan dengan menggunakan pembelajaran 
kooperatif Tipe Teams Games Tournament (TGT) dapat meningkatkan Aktivitas Belajar Akuntansi Siswa.

Implementasi Model Pembelajaran Kooperatif Tipe Teams Games Tournament ini diharapkan dapat meningkatkan Aktivitas dan Hasil Belajar Akuntansi Siswa Kelas X AKL 2 SMK Negeri 1 Pengasih Tahun Ajaran 2019/2020. Model dalam penelitian tindakan kelas ini dapat digambarkan sebagai berikut.

\begin{tabular}{|c|}
\hline Kondisi Awal \\
\hline Aktivitas dan Hasil Belajar Akuntansi siswa masih rendah \\
Menggunakan metode pembelajaran konvensional (ceramah dan kurang \\
bervariasi) \\
\hline Tournament (TGT) pada Kelas X AKL 2 SMK Negeri 1 Pengasih Tahun \\
Ajaran 2019/2020 \\
\hline Tindakan \\
Kondisi Akhir \\
\hline Aktivitas dan Hasil Belajar Akuntansi siswa meningkat \\
\hline
\end{tabular}

Gambar 1 Kerangka Berpikir

Berdasarkan kerangka berpikir tersebut, maka dapat disusun hipotesis tindakan yaitu:

1) Implementasi Model Pembelajaran Kooperatif Tipe Teams Games Tournament (TGT) dapat Meningkatkan Aktivitas Belajar Akuntansi Siswa Kelas X AKL 2 SMK Negeri 1 Pengasih Tahun Ajaran 2019/2020.

2) Implementasi Model Pembelajaran Kooperatif Tipe Teams Games Tournament (TGT) dapat Meningkatkan Hasil Belajar Akuntansi Siswa Kelas X AKL 2 SMK Negeri 1 Pengasih Tahun Ajaran 2019/2020.

\section{METODE PENELITIAN}

Jenis dan Desain Penelitian

Penelitian yang dilakukan adalah Penelitian Tindakan Kelas (Classroom Action Research) dengan bentuk kolaborasi dengan guru mata pelajaran Akuntansi Dasar. Terdapat empat tahapan penting dalam penelitian tindakan kelas, yaitu perencanaan, pelaksanaan tindakan, pengamatan, dan refleksi (Arikunto, dkk, 2017: 42). 


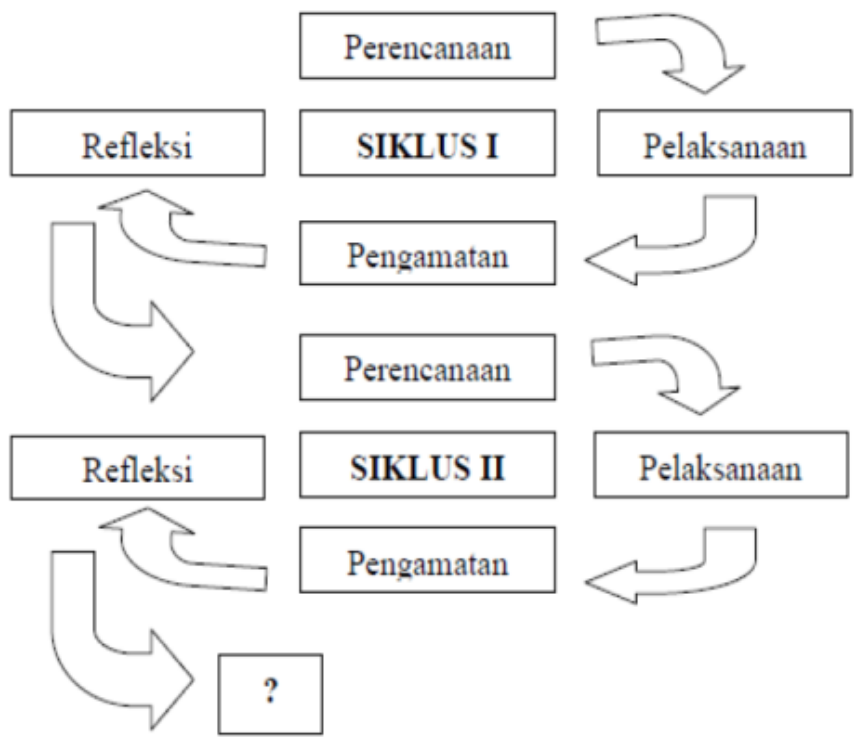

Gambar 2 Model Penelitian Tindakan Kelas

\section{Tempat dan Waktu Penelitian}

Penelitian ini dilakukan di kelas X AKL 2 SMK Negeri 1 Pengasih Tahun Ajaran 2019/2020. Penelitian dilaksanakan pada bulan Januari-Maret 2020. SMK Negeri 1 Pengasih beralamat di jalan Kawijo No. 11, Pengasih, Kulon Progo, Daerah Istimewa Yogyakarta

\section{Subjek dan Objek Penelitian}

Subjek pada penelitian ini adalah siswa kelas X AKL 2 SMK Negeri 1 Pengasih Tahun Ajaran 2019/2020 yang berjumlah 36 siswa. Objek dalm penelitian ini adalah pelaksanaan pembelajaran akuntansi dengan Implementasi Model Pembelajaran Kooperatif Tipe Teams Games Tournament untuk meningkatkan Aktivitas dan Hasil Belajar Akuntansi Siswa Kelas X AKL 2 SMK Negeri 1 Pengasih Tahun Ajaran 2019/2020.

\section{Teknik Pengumpulan Data}

Teknik pengumpulan data dalam penelitian ini yaitu:

1. Obeservasi Partisipatif

Observasi partisipasi adalah observasi dimana peneliti terlibat dengan kegiatan sehari-hari orang yang diamati atau yang digunakan sebagai narasumber penelitian. Observasi dilakukan selama pembelajaran berlangsung yang dilakukan oleh peneliti dan dibantu oleh 2 orang observer. Melalui pedoman observasi yang telah disiapkan, maka akan diperoleh data yang kemudian diterjemahkan untuk mengetahui Aktivitas Belajar pada siklus I dan siklus II penelitian ini yang terdiri dari aktivitas visual, lisan, dan menulis. Observasi ini dilakukan untuk mencari tahu data mengenai kemunculan Aktivitas Belajar pada saat pembelajaran Akuntansi berlangsung di dalam kelas dengan menggunakan Model Pembelajaran Kooperatif Tipe Teams Games Tournament.

2. Tes

Tes dilakukan untuk mengukur Hasil Belajar Akuntansi pada Mata Pelajaran Akuntansi Dasar yaitu materi Jurnal Penyesuaian. Tes diukur berdasarkan Kriteria Ketuntasan Minimal (KKM) yang telah harus dicapai oleh siswa. Tes yang dilakukan dalam penelitian ini adalah pre test dan post test. Post test pada siklus I dan siklus II digunakan untuk menunjukkan Hasil Belajar Akuntansi yang dicapai oleh siswa pada 
masing-masing siklus. Hasil tersebut digunakan untuk mengetahui ketuntasan belajar yang dicapai dan peningkatan Hasil Belajar Akuntansi dengan menggunakan Model Pembelajaran Kooperatif Tipe Teams Games Tournament.

3. Catatan Lapangan

Catatan lapangan merupakan catatan yang digunakan untuk memperoleh data berbagai aspek pembelajaran di kelas, suasana kelas, pengelolaan kelas, hubungan interaksi guru dengan siswa, dan interaksi siswa dengan siswa selama pembelajaran dengan implementasi Model Pembelajaran Kooperatif Tipe Teams Games Tournament.

4. Dokumentasi

Dokumentasi digunakan sebagai pendukung dan penguat data yang diperoleh selama kegiatan penelitian berlangsung. Dokumentasi yang digunakan dalam penelitian ini berupa silabus, RPP, daftar presensi siswa, daftar nilai siswa dan dokumentasi berupa foto saat pembelajaran sedang berlangsung.

\section{Validasi}

Validasi instrumen aktivitas belajar dan tes hasil belajar dalam penelitian ini menggunakan uji validitas isi. Validitas isi merupakan validitas yang diestimasi lewat pengujian terhadap kelayakan atau relevansi isi tes melalui analisis rasional oleh panel yang berkompeten atau melalui expert judgement (penilaian ahli). Peneliti meminta pendapat dari ahli untuk mengevaluasi alat ukur yang telah dibuat. Ahli inilah yang akan menilai apakah alat ukur telah valid atau tidak. Ahli dalam penelitian ini adalah Dosen Jurusan Pendidikan Akuntansi dan guru mata pelajaran Akuntansi Dasar SMK Negeri 1 Pengasih.

\section{Teknik Analisis Data}

Teknik analisis data yang digunakan dalam penelitian ini adalah deskriptif kuantitatif dengan persentase. Analisis data deskriptif kuantitatif digunakan untuk menganalisis data Aktivitas dan Hasil Belajar Akuntansi.

1. Menghitung skor Aktivitas Belajar Akuntansi

a. Menghitung persentase skor Aktivitas Belajar Akuntansi yang diperoleh masingmasing siswa dengan rumus:

$$
\frac{\text { jumlah skor yang diperoleh setiap siswa }}{\text { jumlah skor ideal yang diperoleh siswa }} \times 100 \%
$$

b. Menghitung persentase skor Aktivitas Belajar Akuntansi pada setiap indikator yang diamati dengan rumus:

$$
\frac{\text { jumlah skor setiap indikator }}{\text { jumlah skor maksimum setiap indikator }} \times 100 \%
$$

c. Menghitung persentase rata-rata skor Aktivitas Belajar Akuntansi siswa dengan rumus:

$$
\frac{\text { jumlah skor indikator aktivitas belajar }}{\text { jumlah skor maksimum seluruh indikator }} \times 100 \%
$$

(Sugiyono, 2015: 143-144) 
2. Menghitung Peningkatan Hasil Belajar Akuntansi

a. menghitung rata-rata pre test dan post test yang diperoleh siswa melalui rumus: $M e=\frac{\sum x_{i}}{n}$

Keterangan:

$M e \quad=$ rata-rata $($ Mean $)$

$\Sigma X i \quad=$ jumlah semua nilai

$n \quad=$ jumlah siswa

(Sugiyono, 2015: 49)

b. Menghitung persentase kentutasan belajar siswa dengan rumus:

$K B=\frac{T}{T_{t}} \times 100 \%$

Keterangan:

$\mathrm{KB}=$ Ketuntasan Belajar

$\mathrm{T}=$ Jumlah siswa yang mencapai $\mathrm{KKM}(>75)$

$\mathrm{T}_{\mathrm{t}}=$ Jumlah siswa yang mengikuti tes

(Trianto, 2010: 241)

3. Penyajian Data

4. Penarikan Kesimpulan

\section{HASIL PENELITIAN DAN PEMBAHASAN}

\section{Deskripsi Umum Lokasi Penelitian}

Penelitian ini dilakukan di SMK Negeri 1 Pengasih yang beralamat di Jl. Kawijo No.11, Pengasih, Kecamatan Pengasih, Kabupaten Kulon Progo, Daerah Istimewa Yogyakarta.

\section{Pelaksanaan Tindakan}

Penelitian ini dilaksanakan dalam dua siklus. Masing-masing siklus terdiri dari empat tahapan, yaitu perencanaan, pelaksanaan tindakan, pengamatan, dan refleksi. Data yang disajikan merupakan data dari hasil pengamatan Aktivitas Belajar Akuntansi oleh observer dan tes tertulis Jurnal Penyesuaian.

a. Siklus I

Siklus I dilaksanakan pada hari Senin, 10 Februari 2020 dimulai pukul 09.30-13.35 WIB. Materi yang disampaikan pada pertemuan ini mencakup pengertian jurnal penyesuaian, tujuan penyesuaian, dan jenis-jenis penyesuaian (perlengkapan, beban dibayar di muka, penghasilan diterima di muka, dan pendapatan yang masih harus dibayar). Pembelajaran dimulai dengan pengerjaan soal pre test dan dilanjutkan dengan penyampaian materi oleh guru. Setelah itu, siswa melakukan diskusi dengan kelompok dan melakukan kegiatan games turnamen. Pembelajaran diakhiri dengan siswa mengerjakan soal post test dan pemberian penghargaan kepada kelompok pemenang turnamen. Pengamatan Aktivitas Belajar Akuntansi dapat dilihat pada data berikut.

Tabel 3 Skor Aktivitas Belajar Akuntansi Siklus I Per Indikator

\begin{tabular}{lc}
\hline \multicolumn{1}{c}{ Indikator } & Skor \\
\hline $\begin{array}{l}\text { Siswa memandang guru saat guru menjelaskan materi } \\
\text { pelajaran (secara fisik memperhatikan) }\end{array}$ & $79,05 \%$ \\
\hline $\begin{array}{l}\text { Mengamati demonstrasi guru (secara fisik } \\
\text { memperhatikan) }\end{array}$ & $73,33 \%$ \\
\hline
\end{tabular}




\begin{tabular}{lc}
\hline \multicolumn{1}{c}{ Indikator } & Skor \\
\hline $\begin{array}{l}\text { Membaca materi pelajaran (secara fisik memandang } \\
\text { sumber belajar) }\end{array}$ & $78,10 \%$ \\
\hline Berdiskusi dengan teman saat kegiatan kelompok & $82,86 \%$ \\
\hline $\begin{array}{l}\text { Mengajukan pertanyaan kepada guru saat } \\
\text { pembelajaran atau saat dalam kegiatan kelompok }\end{array}$ & $37,14 \%$ \\
\hline $\begin{array}{l}\text { Siswa memberi jawaban, saran, pendapat, atau } \\
\text { komentar kepada guru atau teman }\end{array}$ & $64,76 \%$ \\
\hline $\begin{array}{l}\text { Mencatat materi yang diberikan atau dijelaskan oleh } \\
\text { guru }\end{array}$ & $79,05 \%$ \\
\hline $\begin{array}{l}\text { Mengerjakan soal dalam pembelajaran yang berupa } \\
\text { pre test dan post test }\end{array}$ & $92,38 \%$ \\
\hline $\begin{array}{l}\text { Menuliskan jawaban pertanyaan saat games } \\
\text { tournament }\end{array}$ & $74,29 \%$ \\
\hline Skor Rata-rata Aktivitas Belajar Akuntansi & Sumber: Data Primer yang Diolah \\
\hline \multicolumn{1}{c}{ Sum } \\
\hline
\end{tabular}

Aktivitas Belajar Akuntansi Siswa per individu dapat dikatakan belum optimal. Hal ini dikarenakan secara individual hanya terdapat 12 siswa $(34,29 \%)$ dari 35 siswa yang memperoleh skor Aktivitas Belajar Akuntansi di atas skor minimal yaitu $75 \%$.

Berdasarkan hasil tes tertulis yang dikerjakan oleh 35 siswa yang hadir pada siklus I, diperoleh data Hasil Belajar Akuntansi Siswa Kelas X AKL 2 sebagai berikut.

Tabel 4 Hasil Belajar Akuntansi Siklus I

\begin{tabular}{ccc}
\hline & Pre Test & Post Test \\
\hline Nilai Tertinggi & 40 & 90 \\
\hline Nilai Terendah & 10 & 50 \\
\hline KKM & 75 & 75 \\
\hline Siswa Lulus KKM & 0 & 23 \\
\hline Siswa Belum Lulus KKM & 30 & 12 \\
\hline Rata-rata & 32,27 & 76,63 \\
\hline Ketuntasan Belajar & $0 \%$ & $65,71 \%$ \\
\hline
\end{tabular}

Sumber: Data Primer yang Diolah

Berdasarkan data tersebut, rata-rata kelas dan ketuntasan hasil belajar mengalami peningkatan. Rata-rata kelas meningkat sebesar 44,36 dan ketuntasan hasil belajar meningkat sebesar $65,71 \%$.

b. Siklus II

Siklus II dilaksanakan pada hari Senin, 17 Februari 2020 dimulai pukul 08.3012.55 WIB. Materi yang disampaikan pada pertemuan ini adalah jenis-jenis penyesuaian (beban yang masih harus dibayar, taksiran piutang tak tertagih, penyusutan aktiva tetap, dan rekonsiliasi bank). Pembelajaran dimulai dengan pengerjaan soal pre test dan dilanjutkan dengan penyampaian materi oleh guru. Setelah itu, siswa melakukan diskusi dengan kelompok dan melakukan kegiatan games turnamen. Pembelajaran diakhiri dengan siswa mengerjakan soal post test dan pemberian penghargaan kepada kelompok pemenang turnamen. Pengamatan Aktivitas Belajar Akuntansi dapat dilihat pada data berikut. 
Tabel 5 Skor Aktivitas Belajar Akuntansi Siklus II Per Indikator

\begin{tabular}{lc}
\hline \multicolumn{1}{c}{ Indikator } & Skor \\
\hline $\begin{array}{l}\text { Siswa memandang guru saat guru menjelaskan materi } \\
\text { pelajaran (secara fisik memperhatikan) }\end{array}$ & $90,48 \%$ \\
\hline $\begin{array}{l}\text { Mengamati demonstrasi guru (secara fisik } \\
\text { memperhatikan) }\end{array}$ & $92,38 \%$ \\
\hline $\begin{array}{l}\text { Membaca materi pelajaran (secara fisik memandang } \\
\text { sumber belajar) }\end{array}$ & $89,52 \%$ \\
\hline Berdiskusi dengan teman saat kegiatan kelompok & $94,29 \%$ \\
\hline $\begin{array}{l}\text { Mengajukan pertanyaan kepada guru saat } \\
\text { pembelajaran atau saat dalam kegiatan kelompok }\end{array}$ & $82,86 \%$ \\
\hline $\begin{array}{l}\text { Siswa memberi jawaban, saran, pendapat, atau } \\
\text { komentar kepada guru atau teman }\end{array}$ & $80,95 \%$ \\
\hline $\begin{array}{l}\text { Mencatat materi yang diberikan atau dijelaskan oleh } \\
\text { guru }\end{array}$ & $80,00 \%$ \\
\hline $\begin{array}{l}\text { Mengerjakan soal dalam pembelajaran yang berupa } \\
\text { pre test dan post test }\end{array}$ & $98,10 \%$ \\
\hline $\begin{array}{l}\text { Menuliskan jawaban pertanyaan saat games } \\
\text { tournament }\end{array}$ & $87,62 \%$ \\
\hline Skor Rata-rata Aktivitas Belajar Akuntansi & $88,47 \%$ \\
\hline \multicolumn{1}{c}{ Sumber: Data Primer yang Diolah } \\
\hline
\end{tabular}

Aktivitas Belajar Akuntansi Siswa per individu dapat dikatakan belum optimal. Hal ini dikarenakan secara individual hanya terdapat 35 siswa (100\%) yang memperoleh skor Aktivitas Belajar Akuntansi di atas skor minimal yaitu 75\%.

Berdasarkan hasil tes tertulis yang dikerjakan oleh 35 siswa yang hadir pada siklus II, diperoleh data Hasil Belajar Akuntansi Siswa Kelas X AKL 2 sebagai berikut.

Tabel 6 Hasil Belajar Akuntansi Siklus II

\begin{tabular}{ccc}
\hline & Pre Test & Post Test \\
\hline Nilai Tertinggi & 54 & 100 \\
\hline Nilai Terendah & 8 & 40 \\
\hline KKM & 75 & 75 \\
\hline Siswa Lulus KKM & 0 & 23 \\
\hline $\begin{array}{c}\text { Siswa Belum Lulus } \\
\text { KKM }\end{array}$ & 36 & 4 \\
\hline Rata-rata & 30,81 & 88,80 \\
\hline Ketuntasan Belajar & $0 \%$ & $88,57 \%$ \\
\hline \multicolumn{2}{c}{ Sumber: Data Primer yang Diolah }
\end{tabular}

Berdasarkan data tersebut, rata-rata kelas dan ketuntasan hasil belajar mengalami peningkatan. Rata-rata kelas meningkat sebesar 57,99 dan ketuntasan hasil belajar meningkat sebesar $88,57 \%$. 


\section{PEMBAHASAN}

\section{Peningkatan Aktivitas Belajar Akuntansi melalui Implementasi Model Pembelajaran TGT}

Aktivitas Belajar Akuntansi secara keseluruhan mengalami peningkatan dari siklus I sebesar $73,44 \%$ menjadi $88,47 \%$ pada siklus II atau meningkat sebesar $15,03 \%$. Secara rinci peningkatan Aktivitas Belajar Akuntansi pada masing-masing indikator dapat dilihat pada gambar berikut.

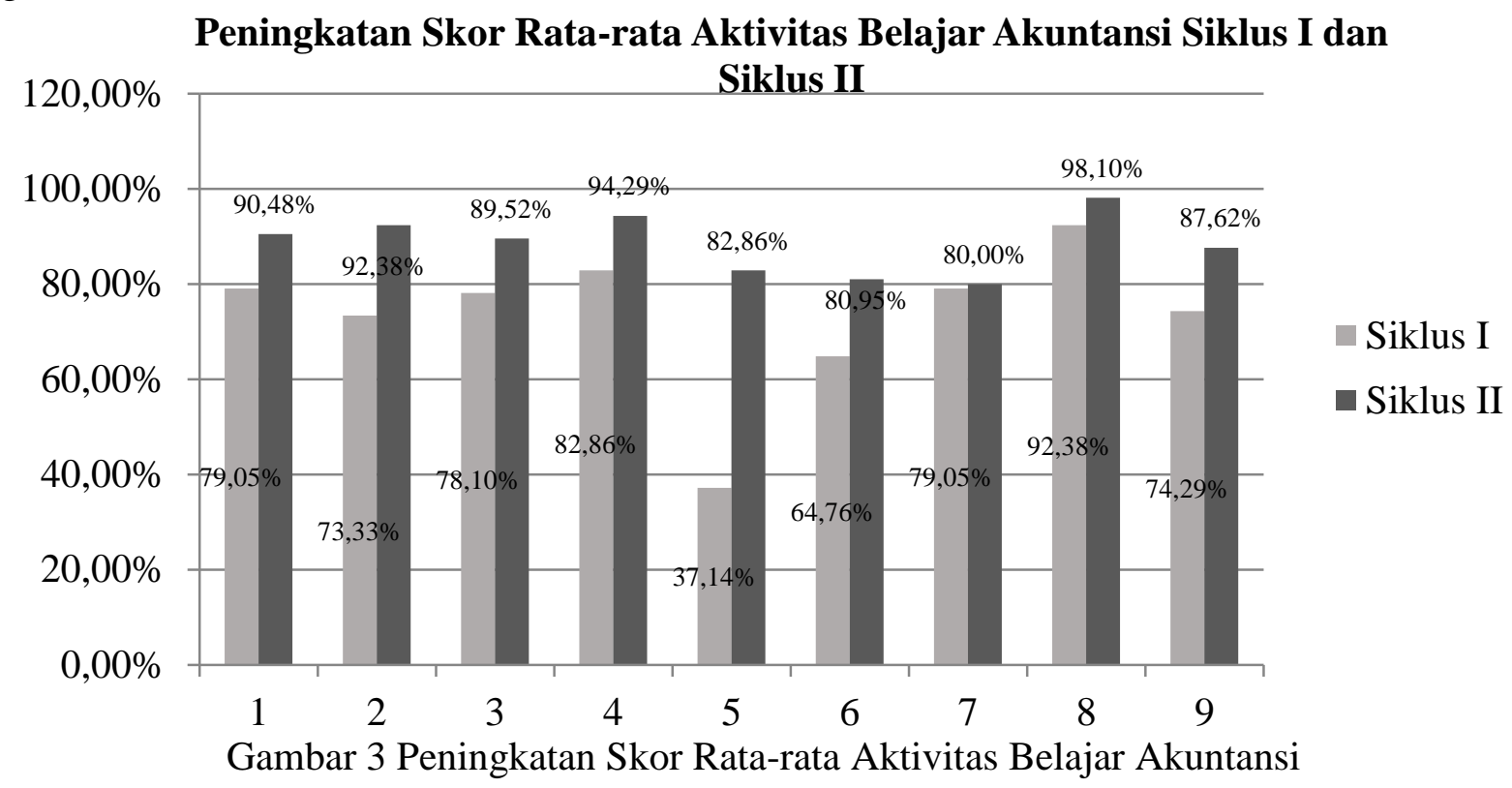

1. Aktivitas Belajar Akuntansi dalam indikator memandang guru saat guru menjelaskan materi pelajaran (secara fisik memperhatikan) mengalami peningkatan skor dari siklus I sebesar 79,05\% menjadi 90,48\% pada siklus II, atau mengalami peningkatan sebesar $11,43 \%$. Peningkatan skor pada indikator ini terjadi karena guru selalu menekankan pada penjelasan materi-materi yang penting. Oleh sebab itu, siswa menjadi lebih fokus dalam memperhatikan penjelasan guru.

2. Aktivitas Belajar Akuntansi dalam indikator mengamati demonstrasi guru (secara fisik memperhatikan) mengalami peningkatan sebesar $19,05 \%$, atau mengalami peningkatan skor dari siklus I sebesar 73,33\% menjadi $92,38 \%$ pada siklus II. Peningkatan skor pada indikator ini terjadi karena guru selalu menekankan ketika akan memberikan contoh untuk pembuatan jurnal penyesuaian. Siswa menjadi fokus memperhatikan demonstrasi guru karena siswa menyadari bahwa harus memahami materi tentang pembuatan jurnal penyesuaian yang akan membantu ketika pelaksanaan games tournament.

3. Aktivitas Belajar Akuntansi dalam indikator membaca materi pelajaran (secara fisik memandang sumber belajar) mengalami peningkatan sebesar $11,43 \%$, atau mengalami peningkatan skor dari siklus I sebesar $78,10 \%$ menjadi $89,52 \%$ pada siklus II. Peningkatan skor pada indikator ini terjadi karena siswa membaca materi dengan seksama untuk berusaha memahami materi secara menyeluruh. Siswa menyadari bahwa dengan memahami materi tentang jurnal penyesuaian secara menyeluruh akan membantu ketika pelaksanaan games tournament.

4. Aktivitas Belajar Akuntansi dalam indikator berdiskusi dengan teman saat kegiatan kelompok mengalami peningkatan skor dari siklus I sebesar 82,86\% menjadi 94,29\% pada siklus II, atau mengalami peningkatan sebesar $11,43 \%$. Peningkatan skor pada indikator ini terjadi karena guru membimbing dan selalu memonitor siswa dalam kegiatan 
diskusi kelompok. Soal latihan yang dikerjakan secara berkelompok memicu siswa dalam berdiskusi untuk mengerjakan tugas dalam kelompok. Kegiatan diskusi berjalan dengan lancar selama sesi diskusi berlangsung.

5. Aktivitas Belajar Akuntansi dalam indikator mengajukan pertanyaan kepada guru saat pembelajaran atau saat dalam kegiatan kelompok mengalami peningkatan skor dari siklus I sebesar $37,14 \%$ menjadi $82,86 \%$ pada siklus II, atau mengalami peningkatan sebesar $45,71 \%$. Peningkatan skor pada indikator ini cukup signifikan. Hal tersebut terjadi karena guru memotivasi dan memberikan kesempatan kepada siswa untuk selalu bertanya apabila terdapat materi yang belum dipahami. Selain itu, guru juga mewajibkan kepada setiap kelompok untuk mengajukan pertanyaan.

6. Aktivitas Belajar Akuntansi dalam indikator memberi jawaban, saran, pendapat, atau komentar kepada guru atau teman mengalami peningkatan skor dari siklus I sebesar $64,76 \%$ menjadi $80,95 \%$ pada siklus II, atau mengalami peningkatan sebesar $16,19 \%$. Peningkatan pada indikator ini juga terjadi karena terjadinya peningkatan pada siswa yang mengajukan pertanyaan. Indikator ini mengalami peningkatan meskipun tidak cukup signifikan seperti indikator mengajukan pertanyaan. Hal tersebut terjadi karena pada siklus I memang sudah cukup banyak siswa yang mengemukakan jawaban maupun pendapatnya. Peningkatan terjadi karena pertanyaan yang diberikan pada siklus II menjadi bertambah lebih banyak dan siswa lebih percaya diri untuk memberikan pendapat secara sukarela.

7. Aktivitas Belajar Akuntansi dalam indikator mencatat materi yang diberikan atau dijelaskan oleh guru mengalami peningkatan sebesar $0,95 \%$, atau mengalami peningkatan skor dari siklus I sebesar 79,05\% menjadi $80,00 \%$ pada siklus II. Peningkatan skor pada indikator ini terjadi karena guru menekankan kepada siswa untuk selalu mencatat materi yang dirasa penting. Peningkatan pada indikator ini merupakan peningkatan terendah di antara 9 indikator lainnya. Hal tersebut terjadi karena siswa sudah dibagikan modul dan membawa buku paket, sehingga masih sedikit siswa masih banyak siswa yang mencatat materi ketika sudah diberikan instruksi oleh guru.

8. Aktivitas Belajar Akuntansi dalam indikator mengerjakan soal dalam pembelajaran yang berupa pre test dan post test mengalami peningkatan sebesar $5,71 \%$, atau mengalami peningkatan skor dari siklus I sebesar 92,38\% menjadi 98,10\% pada siklus II. Peningkatan skor pada indikator ini terjadi karena pada siklus II siswa berupaya untuk mengerjakan seluruh soal dengan benar dalam waktu yang telah disediakan. Oleh karena itu, indikator ini mengalami peningkatan.

9. Aktivitas Belajar Akuntansi dalam indikator menuliskan jawaban pertanyaan saat games tournament mengalami peningkatan skor dari siklus I sebesar 74,29\% menjadi 87,62\% pada siklus II, atau mengalami peningkatan sebesar 13,33\%. Peningkatan skor pada indikator ini terjadi karena pada siklus II siswa berusaha untuk mengerjakan soal turnamen dengan benar dalam waktu yang telah disediakan. Peningkatan juga terjadi selaras dengan peningkatan yang terjadi pada indikator memperhatikan penjelasan dan demonstrasi guru, serta indikator membaca materi pelajaran.

Peningkatan Aktivitas Belajar Akuntansi tertinggi terletak pada indikator mengajukan pertanyaan kepada guru saat pembelajaran atau saat dalam kegiatan kelompok, yaitu sebesar $45,71 \%$. Hal tersebut terjadi karena pada siklus I masih sedikit siswa yang bertanya kepada guru. Guru melakukan upaya agar siswa mempunyai kepercayaan diri untuk mengajukan pertanyaan kepada guru, yaitu dengan memancing siswa untuk bertanya dan selalu memberikan kesempatan kepada siswa untuk bertanya kepada guru. Upaya tersebut mampu meningkatkan jumlah siswa yang bertanya, selain itu pada siklus II juga ditambah dengan 
guru mewajibkan setiap kelompok untuk menyiapkan pertanyaan yang akan diajukan kepada guru.

Peningkatan Aktivitas Belajar Akuntansi terendah terletak pada indikator mencatat materi yang diberikan atau dijelaskan oleh guru, yaitu sebesar $0,95 \%$. Hal tersebut terjadi karena siswa sudah dibagikan modul dan membawa buku paket, sehingga masih sedikit siswa masih banyak siswa yang mencatat materi ketika sudah diberikan instruksi oleh guru. Peningkatan terjadi karena siswa juga masih merasa penting untuk mencatat materi yang diberikan guru, ditambah lagi dengan guru yang selalu mengingatkan untuk mencatat materimateri yang penting.

Peningkatan juga dapat dilihat dari jumlah siswa yang telah mencapai indikator Aktivitas Belajar Akuntansi, yaitu siswa yang memperoleh skor Aktivitas Belajar Akuntansi $\geq$ $75 \%$ pada siklus I dan siklus II. Secara individual, jumlah siswa yang memperoleh skor Aktivitas Belajar Akuntansi $\geq 75 \%$ pada siklus I sebanyak 12 siswa $(34,29 \%)$ meningkat menjadi 35 siswa $(100,00 \%)$ pada siklus II. Hal tersebut menunjukkan bahwa terdapat peningkatan sebanyak 23 siswa $(65,71 \%)$.

Secara garis besar peningkatan tersebut terjadi karena dalam pembelajaran yang terjadi sebelum implementasi Model Pembelajaran Kooperatif Tipe TGT masih terdapat beberapa indikator yang belum optimal, seperti kegiatan diskusi, kegiatan tanya jawab, dan perhatian siswa kepada guru serta materi pelajaran. Setelah implementasi Model Pembelajaran Kooperatif Tipe TGT, indikator-indikator tersebut dapat dikelola oleh guru dengan baik sehingga berjalan lebih optimal. Indikator Aktivitas Belajar Akuntansi menjadi optimal karena kegiatan-kegiatan yang dilaksanakan dalam Model Pembelajaran Kooperatif Tipe TGT.

Peningkatan Aktivitas Belajar Akuntansi pada penelitian ini juga sejalan dengan penelitian yang telah dilakukan oleh Mardiana \& Djazari (2015) tentang Teams Games Tournament dengan Permainan Ludo Akuntansi untuk Meningkatkan Aktivitas Belajar Akuntansi yang menyebutkan bahwa terjadi peningkatan persentase Aktivitas Belajar Akuntansi dari $69,35 \%$ pada siklus I menjadi $88,64 \%$ pada siklus II.

Hal senada juga diungkapkan oleh Rina \& Sukanti (2016) tentang Penerapan Pembelajaran TGT Dengan Roda Putar untuk Meningkatkan Aktivitas Belajar Akuntansi Siswa SMKN 1 Tempel yang membuktikan terjadi peningkatan Aktivitas Belajar Akuntansi dari $71,09 \%$ pada siklus I menjadi $89,84 \%$ pada siklus II.

Berdasarkan hasil penelitian di atas dapat disimpulkan bahwa Implementasi Model Pembelajaran Kooperatif Tipe TGT dapat meningkatkan Aktivitas Belajar Akuntansi Siswa Kelas X AKL 2 SMK Negeri 1 Pengasih Tahun Ajaran 2019/2020 dengan Aktivitas Belajar Akuntansi mencapai minimal $75 \%$. Hal tersebut sejalan dengan yang dikemukakan oleh Mulyasa (2013: 218) bahwa dilihat dari segi prosesnya, pembelajaran dikatakan berhasil dan berkualitas apabila seluruhnya atau setidak-tidaknya sebagian besar (75\%) siswa terlibat secara aktif, baik fisik, mental, maupun sosial dalam proses pembelajaran. Dengan demikian, hipotesis tindakan dalam penelitian ini dinyatakan sudah terjawab.

\section{Peningkatan Hasil Belajar Akuntansi melalui Implementasi Model Pembelajaran TGT}

Rata-rata Hasil Belajar Akuntansi pada pre test siklus I sebesar 32,27 meningkat menjadi 76,63 pada post test atau meningkat sebesar 44,36. Pada siklus II, rata-rata Hasil Belajar Akuntansi pre test sebesar 30,81 meningkat menjadi 88,80 pada post test atau meningkat sebesar 57,99. Peningkatan rata-rata Hasil Belajar Akuntansi pada siklus I dan siklus II dapat dilihat pada gambar berikut. 


\section{Peningkatan Rata-rata Hasil Belajar Akuntansi pada Siklus I dan} Siklus II

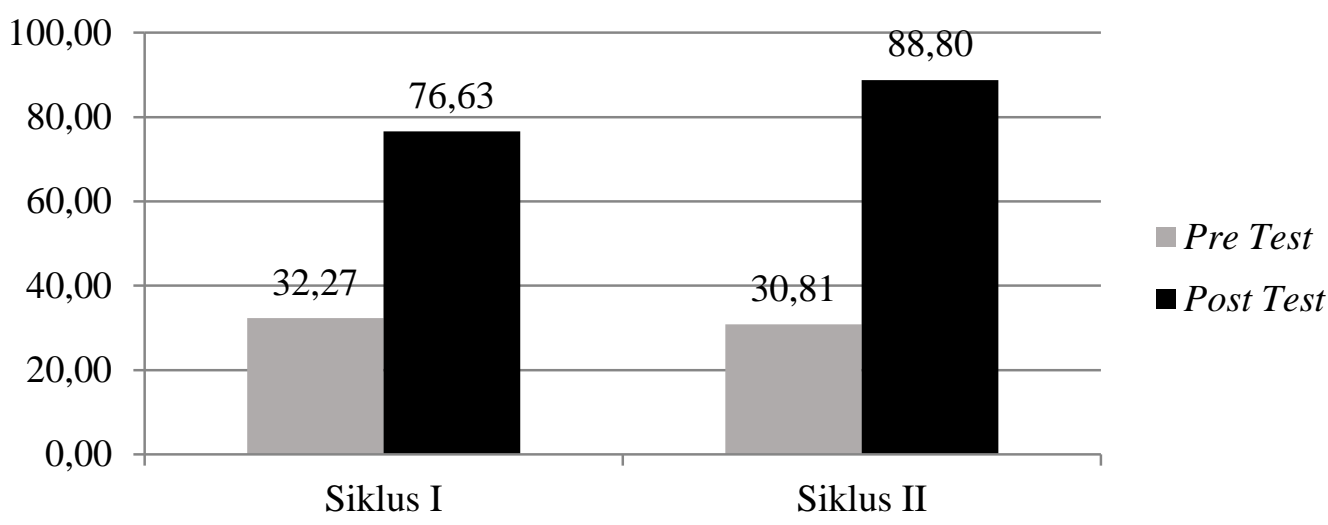

Gambar 4 Peningkatan Rata-rata Hasil Belajar Akuntansi

Data penelitian tersebut membuktikan bahwa implementasi Model Pembelajaran Kooperatif Tipe TGT dapat meningkatkan Hasil Belajar Akuntansi. Hal ini sejalan dengan teori yang dikemukakan oleh Suarjana dalam Ertikanto (2016: 105-106), bahwa pembelajaran dengan Model Pembelajaran Teams Games Tournament hasil belajar akan menjadi lebih baik. Hasil penelitian ini senada dengan yang telah dijelaskan pada penelitian Lestari \& Sukanti (2017) yang berjudul Implementasi Model TGT untuk Meningkatkan Aktivitas Belajar dan Hasil Belajar Akuntansi. Penelitian tersebut membuktikan bahwa nilai rata-rata Hasil Belajar Akuntansi pada pre test sebesar 45,82 meningkat menjadi sebesar 85,00 pada post test dan pada pre test siklus II sebesar 42,54 meningkat menjadi sebesar 82,40 pada post test.

Peningkatan Hasil Belajar Akuntansi juga dapat dilihat dari peningkatan ketuntasan Hasil Belajar Akuntansi pada siklus I dan siklus II yang disajikan dalam tabel berikut.

Tabel 7 Peningkatan Ketuntasan Hasil Belajar Akuntansi

\begin{tabular}{cccc}
\hline \multirow{2}{*}{ Siklus } & Pre Test & Post Test & Peningkatan \\
\cline { 2 - 4 } & $\%$ & $\%$ & \\
\hline I & $0,00 \%$ & $65,71 \%$ & $65,71 \%$ \\
\hline II & $0,00 \%$ & $88,57 \%$ & $88,57 \%$ \\
\hline \multicolumn{4}{c}{ Sumber: Data Primer yang Diolah }
\end{tabular}

Ketuntasan Hasil Belajar Akuntansi pada post test siklus I 65,71\% meningkat menjadi $88,57 \%$ pada post test siklus II, atau meningkat sebesar 22,86\%. Hasil tersebut senada dengan hasil penelitian Nita Lestari (2017) yang mengungkapkan ketuntasan Hasil Belajar Akuntansi pada pre test siklus I sebesar $12,12 \%$ meningkat menjadi sebesar $72,73 \%$ pada post test dan ketuntasan Hasil Belajar Akuntansi meningkat dari pre test siklus II sebesar 0,00\% menjadi sebesar $78,57 \%$ pada post test.

Apabila ketuntasan Hasil Belajar Akuntansi pada siklus I dan siklus II penelitian ini dibandingkan, maka peningkatan ketuntasan Hasil Belajar Akuntansi pada siklus II menunjukkan peningkatan yang lebih besar daripada peningkatan yang terjadi pada siklus I. Ketuntasan Hasil Belajar Akuntansi pada siklus II telah mencapai indikator keberhasilan yang telah ditentukan. Hal tersebut terjadi karena ketuntasan Hasil Belajar Akuntansi sudah mencapai lebih dari $75 \%$, yaitu sebesar $88,57 \%$. Data hasil penelitian tersebut menunjukkan bahwa implementasi Model Pembelajaran Kooperatif Tipe TGT dapat meningkatkan Hasil 
Belajar Akuntansi. Dengan demikian, hipotesis tindakan dalam penelitian ini dinyatakan sudah terjawab.

\section{KESIMPULAN}

1. Implementasi Model Pembelajaran Kooperatif Tipe Teams Games Tournament (TGT) dapat meningkatkan Aktivitas Belajar Akuntansi Siswa Kelas X AKL 2 SMK Negeri 1 Pengasih Tahun Ajaran 2019/2020. Hal tersebut dibuktikan dengan peningkatan skor rata-rata Aktivitas Belajar Akuntansi dan peningkatan jumlah siswa yang memperoleh skor Aktivitas Belajar Akuntansi $\geq 75 \%$ dari siklus I ke siklus II. Skor rata-rata Aktivitas Belajar Akuntansi meningkat dari siklus I sebesar 73,44\% menjadi 88,47\% pada siklus II, atau meningkat sebesar 15,03\%. Jumlah siswa yang memperoleh skor Aktivitas Belajar Akuntansi $\geq 75 \%$ pada siklus I sebanyak 12 siswa (34,29\%) meningkat menjadi 35 siswa $(100,00 \%)$ pada siklus II, atau meningkat sebanyak 23 siswa $(65,71 \%)$.

2. Implementasi Model Pembelajaran Kooperatif Tipe Teams Games Tournament (TGT) dapat meningkatkan Hasil Belajar Akuntansi Siswa Kelas X AKL 2 SMK Negeri 1 Pengasih Tahun Ajaran 2019/2020. Hal tersebut dibuktikan dengan peningkatan nilai rata-rata Hasil Belajar Akuntansi dan peningkatan ketuntasan Hasil Belajar Akuntansi dari siklus I ke siklus II. Rata-rata Hasil Belajar Akuntansi pada pre test siklus I sebesar 32,27 meningkat menjadi 76,63 pada post test. Pada siklus II, rata-rata Hasil Belajar Akuntansi pre test sebesar 30,81 meningkat menjadi 88,80 pada post test. Ketuntasan Hasil Belajar Akuntansi pada pre test siklus I sebesar 0\% meningkat menjadi 65,71\% pada post test, atau meningkat sebesar $65,71 \%$. Pada siklus II, Ketuntasan Hasil Belajar Akuntansi pada pre test sebesar 0\% meningkat menjadi 88,57\% pada post test, atau meningkat sebesar $88,57 \%$.

\section{DAFTAR PUSTAKA}

Amin, T.A., Yahya, M., \& Caronge, M. W. (2018). Penerapan Model Pembelajaran Kooperatif Tipe TGT untuk Meningkatkan Hasil Belajar Membiakkan Tanaman Secara Vegetatif Pada Siswa Kelas X SMK Negeri 3 Takalar. Jurnal Pendidikan Teknologi Pertanian, 4, 73-81.

Arikunto, S., Suhardjono, \& Supardi (2016). Penelitian Tindakan Kelas. Jakarta: PT Bumi Aksara.

Ertikanto, C. (2016). Teori Belajar dan Pembelajaran. Yogyakarta: Media Akademi.

Lestari, N. \& Sukanti. (2017) "Implementasi Model TGT untuk Meningkatkan Aktivitas Belajar dan Hasil Belajar Akuntansi”. Jurnal Pendidikan Akuntansi Indonesia. Vol. XV No. 1. Hal 1-9.

Mardiana, S. \& Moh. Djazari (2015) "Teams Games Tournament dengan Permainan Ludo Akuntansi untuk Meningkatkan Aktivitas Belajar Akuntansi”. Jurnal Pendidikan Akuntansi Indonesia. Vol. XIII No. 1. Hal 55-64.

Mulyasa. (2013). Implementasi Kurikulum Tingkat Satuan Pendidikan Kemandirian Guru dan Kepala Sekolah. Jakarta: PT Bumi Aksara.

Rina, N. I. \& Sukanti (2016) "Penerapan Pembelajaran TGT Dengan Roda Putar untuk Meningkatkan Aktivitas Belajar Akuntansi Siswa SMKN 1 Tempel". Jurnal Pendidikan Akuntansi Indonesia. Vol. XIV No. 1. Hal 35-44.

Rusman (2016). Seri Manajemen Sekolah Bermutu Model-model Pembelajaran Mengembangkan Profesionalisme Guru. Jakarta: PT RajaGrafindo Persada. 
Sanjaya, W. (2016). Strategi Pembelajaran Berorientasi Standar Proses Pendidikan. Jakarta: Kencana Prenada Media Group.

Sardiman. A.M. (2016). Interaksi dan Motivasi Belajar Mengajar. Jakarta: PT RajaGrafindo Persada.

Slavin, R.E. (2016). Cooperative Learning Teori Riset dan Praktik (Alih bahasa: Narulita Yusron). Bandung: Nusa Media.

Sudjana, N. (2014). Penilaian Hasil Proses Belajar Mengajar. Bandung: PT. Remaja Rosdakarya.

Sugiyono. (2015). Statistika untuk Penelitian. Bandung: Penerbit Alfabeta.

Trianto. (2010). Mendesain Model Pembelajaran Inovatif-Progresif: Konsep Landasan, dan Implementasinya pada Kurikulum Tingkat Satuan Pendidikan (KTSP). Jakarta: Kencana Prenada Media Group. 